\title{
A Conceptual Approach to Studying the Organisational Culture of Construction Projects
}

Thayaparan Gajendran, (The University of Newcastle, Australia)

Graham Brewer, (The University of Newcastle, Australia)

Andrew Dainty, (Loughborough University, UK)

Goran Runeson, (University Technology of Sydney, Australia)

\begin{abstract}
Studying the culture of project organisations requires a robust theoretical framework, which provides a platform for generating understanding. It is proposed that cultural analysis frameworks are most effectively conceptualised from multiple philosophical and multimethodological positions. The goal of the present paper is to describe a cultural analysis framework for studying construction project organisations, based on a synthesis of the culture literature. Four key aspects underpinning organisational cultural frameworks are explored: the paradigms used to conceptualise organisational culture, the methods by which individuals represent and assess cultural dimensions, the cultural perspectives assumed by the observer when defining and describing culture, and the managers' orientation toward culture in their organisations. The proposed framework comprises three synthesised cultural philosophical positions: integration-technical, differentiation-practical and fragmentationemancipation. These philosophical positions span the polar extremes defining the cultural paradigm continuum, which and when combined provide researchers and organisational managers with a sound foundation from which to study the culture of project organisations.
\end{abstract}

Keywords: Culture, Cultural Analysis, Project Organisation, Integration, Fragmentation

\section{Introduction}

Attention to cultural issues in the construction industry, both in the form of permanent and temporary project organisations, has gained significant momentum in recent times (Fellows 2010). Moreover, the increasing internationalisation of construction also warrants better understanding of cross-national cultural practices (Tijhuis and Fellows 2012). Industry reviews (e.g. Latham 1994; Egan 1998) have cited culture as an impediment to the industry's functioning and wellbeing. In the light of such reviews, researchers have focused on studying issues perceived as being connected to culture with the view to improving industry performance. However, the tendency to treat culture solely as a variable that can be manipulated for improvement is not an amenable enough conceptualisation of culture to shed meaningful insight into the ills of the construction industry (Green 2011).

The culture as a variable within an organisation or project, the 'Functional paradigm, is amenable to control and thereby could contribute to organisational performance. Evaluation of selected literature reveals that the key motivation of cultural studies in construction was to develop empirical understandings of the impact of culture upon different construction industry issues, to assist with some form of performance improvement. Although performance focus is critical for organisational development, studies focussing solely on manipulation of culture for performance improvement will not develop adequate and meaningful understanding of project organisations (Alvesson 2002).

One of the cultural research issues focused on since the nineties is managing the adversarial attitudes arising out of procurement (Cheng et al. 2004; Walker et al. 2001) and contractual (Phua \& Rowlinson 2003) approaches to improve the landscape of the construction industry. Impact of the differences in the cross-national cultures on construction organisations (Pheng \& Yuquan 2002; Ling, Ang \& Lim 2007; Zou et al. 2007; Ankrah, Proverbs, \& Debrah 2009) is another key research issue that is focused on project 
improvement. Cultural studies also centre on developing an understanding of professional cultures (Ankrah \& Langford 2005), including behaviour of professions (Liu \& Fellows 2008) and ethical disposition of professions (Liu, Fellows \& $\mathrm{Ng} 2004$ ).

Cultural issues associated to improved knowledge transfer in project organisations (Brochner, Rosander \& Waara 2004), topologies of corporate culture of construction firms (Igo \& Skitmore 2006) and motivational aspects in the construction workplace (Smithers \& Walker 2000; Hartmann 2006) have also been studied. In the same period, influence of culture on ICT system implementation (Anumba et al. 2006) and construction safety (Root 2005; Nielsen 2007) was explored. Most of the above studies, although having mobilised various methodological approaches, essentially seek to understand, or change, cultures (Cheung et al 2011; Price \& Chahal 2006) for improved performance of project organisations; a position closely associated to the functional paradigm.

Despite the empirical contributions of these recent studies to the understanding of the impact of culture in project organisations, it can be argued that use of a non-functional approach (Adriaanse and Voordijk 2005; Rooke, Seymore \& Fellows 2003, 2004) to study culture, could provide an attentive lens.

Essentially, researchers assume a philosophical position(s), explicitly or implicitly, when conducting cultural studies. Their position(s) will influence the choice of methodologies employed to assess culture. As way of example, research that uses existing frameworks such as Hofstede's cross-cultural analysis framework (see Hofstede 2010) and Carmon and Quinn's competing values framework (2006), are grounded in functional paradigm. Although proven popular, these frameworks are set in a pre-determined singular philosophical position, offering limited flexibility for researchers wishing to combine multiple philosophical positions. Moreover, Nakata (2009) suggests that it is time to look beyond Hofstede for constructing alternative cultural frameworks for global marketing and management.

This paper offers a conceptual 'cultural analysis' framework that serves dual purposes in analysing organisational cultures. Firstly, it simplifies and guides cultural studies of organisations, providing a framework against which cultures can be defined, evaluated and understood. Secondly, it assists in designing a suitable cultural assessment approach, from multiple cultural philosophical positions, to study cultures in practice. It will be argued that a more in-depth and comprehensive understanding of organisational cultures within construction project organisations can be garnered from such a cultural analysis approach.

\section{Cultural Assessment: a Background}

Complicating this cultural framing is the fact that a single definition of culture does not exist, and the characteristics of culture have not yet been consistently agreed upon. Despite this lack of agreement, consistent efforts have been made in recent years to transcend the intellectual debate through a broad conceptualisation of culture (e.g. Martin, Frost \& O'Neill 2004) focusing on the underlying assumptions, beliefs and values (referred to as "cultural manifestations') of groups. These factors are transmitted as cultural meanings that guide the way a group thinks, feels and acts. The culture of an organisation can then be characterised, based on to what extent the 'underlying beliefs' are shared and other associated cultural manifestations within a group and among groups (Schein 2004; Alvesson 1993a, 1993b, 2002). The level of harmony or ambiguity will be reflected in the environments in which the group(s) operates.

Cultural analysis accommodates multiple philosophical positions, allowing researchers to engage with culture by drawing on differing theoretical standpoints (Martin 2004). This paper constructs such a synthesised cultural analysis framework by drawing from a number of philosophical positions, an approach which assists in the investigation of cultures as part of project organisations. Initially, two cultural paradigms, 'functional' and 'non-functional', are

Gajendran et al. (2012) 'A conceptual approach to studying the organisational culture of construction projects', Australasian Journal of Construction Economics and Building, 12 (2) 1-26 
discussed to explain the fundamental difference in the way culture is conceptualised in organisational studies.

Various levels of cultural manifestation are identified, including their characteristics and how they represent organisational culture, resulting in a number of definitions of culture being presented. The discussion then leads to three cultural perspectives: integration, differentiation and fragmentation, that conceptualise culture according to the ways in which cultural manifestations are shared in organisations. The three cultural philosophical orientations (a) technical (b) practical and (c) emancipatory, are introduced in order to illustrate how each perspective tends to deal with culture. Finally, these three perspectives and orientations are synthesised to form a cultural analysis framework, philosophical positions that provides a unique and comprehensive approach to studying specific project organisations.

\section{Culture in Organisations: a Review of the Cultural Paradigms}

The literature on organisational culture shows an enormous variation in the conceptualisations, definitions and approaches of research, due to the influence from various disciplines and schools of thought (Alvesson 2002; Martin, Frost \& O'Neill 2004; Rousseau 1990). Philosophical conceptualisations of culture are generally divided between; (a) the concept of real, objective and functionalist 'out there' phenomena (Davis 1985; Deal and Kennedy 1988; Denison \& Mishra 1995; Ouchi 1981; Peters and Waterman 1982) and (b) a non-functional paradigm for thinking about the social world or social reality in organisations (Smircich 1983b, 1985; Smircich \& Calas 1995; Morgan 1980; Alvesson 1987; Denison 1996).

The difference in cultural research methodologies is underpinned by the expected outcomes of cultural studies; that is, whether the outcomes are 'context specific' or 'generalisable to the population'. Generally, researchers who ascribe to quantitative research (e.g. statistical inference, large sample sizes, reliability and validity measures) seek generalisable cultural analysis outcomes. However, researchers who undertake qualitative research and context specific analysis (e.g. ethnography) argue that the goal of cultural analysis is to provide an interpretative frame within a cultural context (Martin 2004). These methodological divisions are also reflected in conceptualisations of organisational culture. As indicated previously, these concepts are divided into two polar categories-the functional and non-functional view, as Smircich (1983a: 354) describes below:

Some researchers give high priority to the principles of prediction, generalisability, causality, and control; while others are concerned by what appear to them to be more fundamental issues of meaning and the process by which organisational life is possible.

Arguably, combining these perspectives through a blend of both approaches offers a more complete understanding. Although this raises issues around the commensurability of the knowledge that they respectively generate, such a suggestion is broadly in line with wider assertions as to the need to mobilise multiple perspectives in project management research in the pursuit of 'middle range' theories (Söderlund 2004; Green and Schweber 2008).

\section{Culture as a Variable vs. Root Metaphor: the Difference between Functional Paradigm and non-Functional Paradigm}

Viewing culture as a variable subject to conscious manipulation, provides a simplified and functional approach to cultural understanding. From this perspective, it is possible to manage culture and to link culture to organisational performance implying a causal relationship. Researchers who embrace the 'variable' view of culture rely on a traditional functionalist framing of social reality, approaching culture as one variable among many others (communication, organisational structure, strategy, etc.) in an organisation. This 
approach also asserts that organisational operations are embedded in cultural symbols (e.g. rituals, values or norms) and that through the modification of member behaviours, changes in organisational outcomes can be achieved. Therefore, studies of culture that adopt this view propose that culture is linked to organisational performance. Moreover, positive virtues, attitudes and behaviours are claimed to be useful in achieving corporate goals and these relevant dynamics can, and should, be manipulated for corporate performance (Deal and Kennedy 1988; Ouchi 1981).

In the functional view, instrumental reasons dominate the discussion of culture, with the emphasis on economic growth, advancement of technology and the exploitation of nature (Deal and Kennedy 1988; Ouchi 1981; Ouchi \& Wilkins 1985; Wilkins 1983; Wilkins \& Ouchi 1983; O'Reilly, Chatman \& Cadwell 1991). According to Alvesson (2002), this has led to research on corporate culture, which focuses on values that directly relate to the organisation's effectiveness and state of success. He argues against equating the 'strong' cultures, which are characterised as advantageous to firms, to those 'valuable' cultures that foster 'good' performance in general (e.g. values supportive of excellence, team work, profitability, honesty). The consequence of the functionalist approach is that culture is reduced to those limited aspects that are perceived to influence organisational efficiency.

Researchers who avoid such notions of a causal link between culture and organisational performance argue that this view is simplistic and seriously underestimates the theoretical potential and value of culture (Alvesson 1993b, 2002; Meyerson 1991a, 1991b, 1994; Meyerson \& Martin 1987; Geertz 1975). They favour a non-functional approach to culture whereby culture is 'thickly', or more comprehensively, described. Such 'thick descriptions' do not merely attempt to explain human behaviour, but its context as well, such that the behaviour becomes meaningful to an outsider. This notion of 'thick descriptions', originally coined by Clifford Geertz to describe his ethnographic methodology (Geertz 1975), has gained widespread recognition in the social sciences and beyond. In organisational studies, this paradigm supports the study of the informal aspects of organisations - aspects that may be obscured, paradoxical and contradictory. Thus, such descriptions offer radically differing perceptions of culture and its consequences within organisations, as has been revealed within a project context (de Bony 2010).

Contrary to the view that culture is something that an organisation can possess and command, proponents of the 'root metaphor' view stress that the organisation is itself a culture, or a collection of cultures. This philosophical position has its roots in anthropology and sociology (Geertz 1975). The proponents of a 'root metaphor' approach argue that cultures are organisations-whereby culture is a context in which social events, behaviours, and institutions materialise. Smircich (1983a, p 348) describes this approach below:

Culture as a root metaphor promotes a view of organisations as expressive forms, manifestations of human consciousness. Organisations are understood and analysed not mainly in economic or material items, but in terms of their expressive, ideational, and symbolic aspects.

According to this view, the social world is constructed by people and reproduced by the networks of symbols and meanings that people share (Burrell \& Morgan 1979). The root metaphor conceptualisation of culture emphasises a more general understanding of, and reflection upon, cultural settings. Advocates of the root metaphor approach oppose the view that organisational effectiveness can be attained through direct cultural manipulation, as this fails to address the negative features of peoples' behaviour such as resistance to change. Those who adopt this approach shun simplistic, objectivist, functionalist views of culture which link culture to performance, preferring a practical/blended conceptualisation of culture. Such a perspective has been mobilised in project management research with respect to managing cultures (see Marrewijk 2007; Marrewijk et. al. 2008).

Gajendran et al. (2012) 'A conceptual approach to studying the organisational culture of construction projects', Australasian Journal of Construction Economics and Building, 12 (2) 1-26 


\section{Cultural Manifestations}

The two key paradigms of culture described above are also associated with certain cultural manifestations and definitions. Manifestations are a critical component of the conceptualisation of culture as they are the aspects that enable culture to be felt, observed and deciphered. The literature suggests that culture can be assessed via different levels of cultural manifestation (e.g. shallow to deep). The level of manifestation also impacts on the ability to decipher and study culture. Marrewijik (2007) and Cheung, Wong and Wu (2011) have discussed the use of cultural manifestations in relation to project management research and emphasised the need for using appropriate manifestations to decipher culture.

\section{Levels of Cultural Manifestations}

Researchers hold varying views on the manifestations that represent culture. This has led to the classification of cultural manifestations into a number of levels, each based on how deeply and accurately they decipher cultures. Hofstede (1998a, p. 479) indicates that:

Culture is a characteristic of the organisation, not individuals, but it is manifested in and measured from the verbal and/or non-verbal behaviour of individuals-aggregated to the level of the organisational unit.

The cultural model in Figure 1(a), developed by Hofstede et al. (1990, 2001), identifies symbols, rituals and heroes as manifestations. He believes that these manifestations are exposed or brought to the surface by practices adopted by organisations. However, he proposes 'value' as a deep manifestation of culture and uses it to decipher cultures (Hofstede 1998a; Hofstede et al.1990). Schein (2004) identifies a number of attributes that are used to describe culture. They include observed behavioural irregularities, group norms, espoused values, shared meanings, root metaphors, formal rituals and celebrations. However, Schein $(1984,2004)$ articulated all attributes into three levels of cultural manifestations, namely 'artefacts', 'espoused values and beliefs', and 'underlying assumptions'. A model developed by Rousseau (1990), Figure 1(b), is consistent with Schein's model, but identifies two more layers of cultural manifestations, namely 'behavioural norms' and 'patterns of behaviour'.
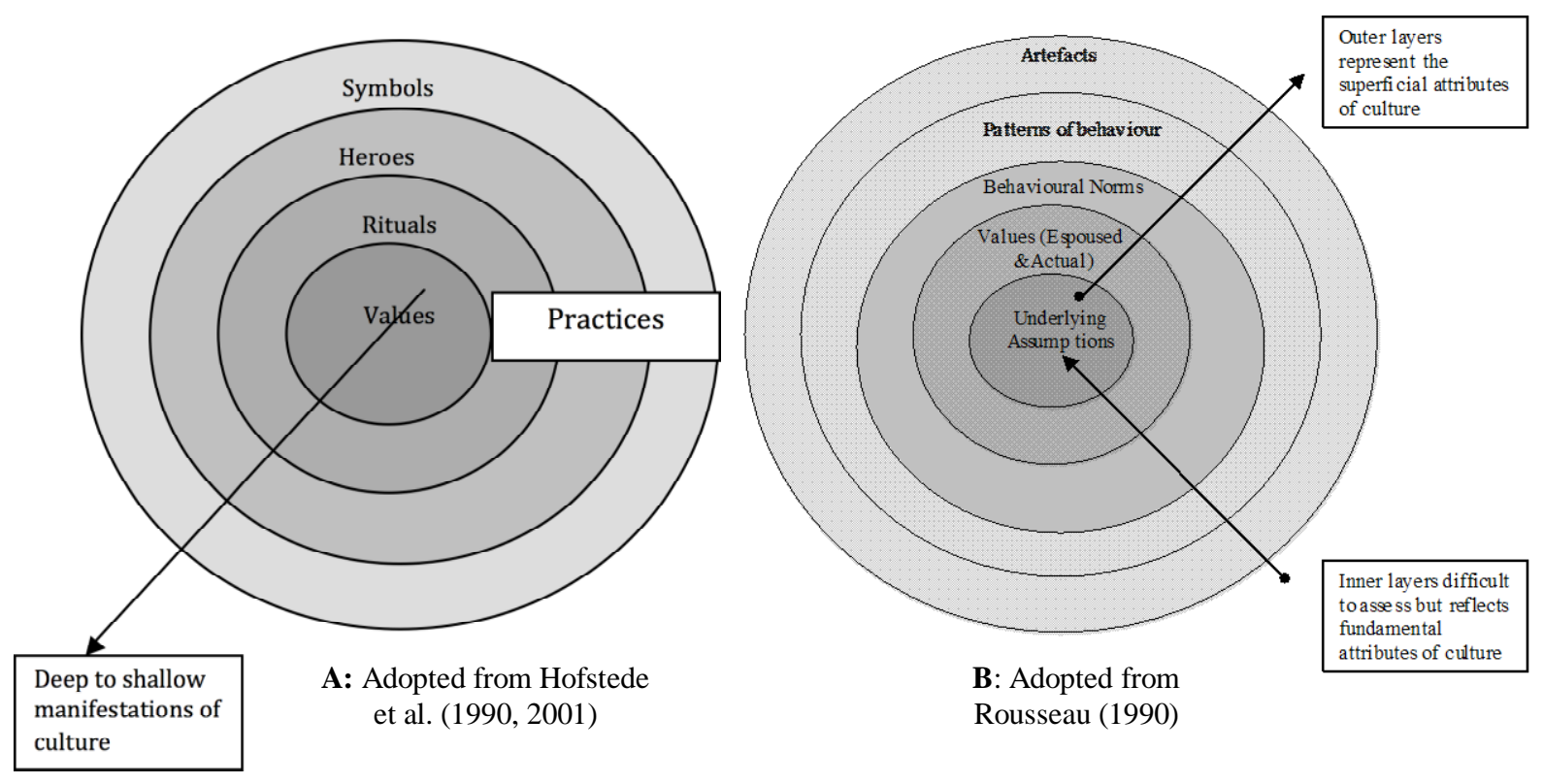

Figures 1(a) \& 1(b) Different layers of cultural manifestations proposed by Hofstede et al. (1990) and Rousseau (1990)

Gajendran et al. (2012) 'A conceptual approach to studying the organisational culture of construction projects', Australasian Journal of Construction Economics and Building, 12 (2) 1-26 
It is believed that artefacts, such as patterns of behaviour and behavioural norms, are the more visible parts of culture. Values (that is, espoused values) are generally reflected in the goals and strategies of an organisation. The underlying assumptions/beliefs generally represent unconscious or taken-for-granted perceptions or beliefs. Taken-for-granted assumptions are powerful and deep-seated, and are thus more difficult to detect than espoused values. Based on their philosophical position, researchers employ different cultural manifestations to decipher culture.

\section{Use of Cultural Manifestations in the Assessment of Culture}

The most appropriate manifestations to use to decipher culture are highly contested within the literature. Early popular cultural studies (Deal \& Kennedy 1988; Peters \& Waterman 1982; Ouchi 1981) focused on the outer layers of manifestations, such as artefacts and patterns of behaviour, and linked culture to organisational performance. These studies favour the 'functional-variable' paradigm of culture. Schein $(1993,2004)$ and Rousseau (1990), however, have stressed the importance of in-depth understanding, labelling artefacts as 'superficial'. Indeed, Schein (1984, 1990, 2004) discourages the analysis of organisational culture through the 'visual artefacts' of the constructed environment (e.g. the architecture, technology, office layout, dress code, behaviour patterns, public documentation, employee orientation and stories). Alvesson (2002) also agrees that employing artefacts in cultural analysis can be misleading. For example, he suggests that trying to understand organisational culture by studying the coffee breaks, dress code, and meeting arrangements, may not give the best insight into culture. Both Schein (2004) and Alvesson (2002) argue that the surface level cultural data are easy to obtain but difficult to analyse and decipher. Although this level of analysis describes behavioural patterns, it does not explain why a group behaves in a particular way.

To explain why the artefacts and patterns of behaviour have certain characteristics, studies need to analyse the underlying assumptions/beliefs and values. Therefore, it is suggested that a study of culture should focus on the underlying, or 'taken-for-granted' assumptions and orientations, rather than the customary behaviour of a group of people. Understanding the underlying assumptions will enable identification of the reasons for conflict, ambiguity and self-contradiction in organisations and groups (Meyerson \& Martin 1987; Alvesson 1993b). Extracting deep and inner layers of manifestations generally involves ethnographic methodologies and interviews with key members of an organisation (Morse \& Richards 2002; Schein 1993).

\section{Cultural Perspectives and Orientations}

In addition to manifestations of culture, there is also a range of cultural perspectives that emerge from the paradigms of culture. The cultural definitions can be clustered into three cultural perspectives integration, differentiation, and fragmentation as proposed by Martin $(1992,2002,2004)$ that span the two extreme intellectual cultural paradigms. The three perspectives act to distinguish cultures based on how cultural manifestations are shared among the unit/organisation (the 'shared nature of culture'). The cultural definitions, by associating cultural perspectives, also differ based on their view of how cultural manifestations should be, or are, shared within a cultural unit (Martin 2004).

In revealing organisational cultures, it is important to give attention to the role of the cultural perspectives as they provide an account of the mind-set or belief influencing different forms of cultural studies. The kind of cultural understanding developing in the project management domain is deeply rooted in the way the cultural studies are designed; essentially, which of the above perspectives is adopted by the researchers. The key aspects that distinguish the three cultural perspectives are; how culture is shared, how boundaries are conceived, and how ambiguity is associated in organisations.

Gajendran et al. (2012) 'A conceptual approach to studying the organisational culture of construction projects', Australasian Journal of Construction Economics and Building, 12 (2) 1-26 
In addition to the perspectives, culture literature also discusses three types of cultural orientation to demonstrate approaches; technical, practical and emancipation, that organisations employ to intervene with culture. These three cultural orientations distinguish intervention approaches e.g. 'control' to manipulate culture or 'emancipate' to transform cultures based on the assumptions of how cultural manifestations should be shared among the unit/organisation (Alvesson 2002). Shifting from technical and practical, to emancipation orientations also relates to a move from 'culture is controllable/pro-management of culture' to 'culture is not controllable/anti-management of culture' (Alvesson and Willmott, 1992).

\title{
A Philosophical Framework for Cultural Analysis
}

Based on the above discussion, it is clear that the most effective cultural analyses attempt to decipher culture from deeper manifestations and assess whether they are consistent (shared) or inconsistent (not shared) with other cultural manifestations in organisations. Project organisational culture can be comprehensively described as follows:

\begin{abstract}
Culture is a set of deeply held beliefs or underlying assumptions possessed by the individuals that make up groups in organisations, which provide a means to understand the values, behaviours and artefacts exhibited by the group. The underlying cultural beliefs that manifest themselves in groups in an organisation may be in harmony (shared) or in conflict (unshared), sometimes displaying apparent ambiguity, paradox or contradiction. The level of harmony or ambiguity among beliefs, values, behaviours and artefacts will impact upon the emergent culture and shapes organisational environments in which the group operates.
\end{abstract}

In support of the above cultural description, a cultural analysis framework, developed as part of a synthesized outcome of this review, identifies three philosophical positions in relation to conceptualising, interpreting and managing culture.

\section{Overview of the Conceptual Framework for Cultural Analysis}

The framework presented in Table 1 presents three philosophical positions from cultural studies: integration-technical, differentiation-practical and fragmentation-emancipatory. In essence, two philosophical paradigms proposed by Smircich (1983a) are aligned to Martin's three cultural perspectives to provide a platform on which to build a cultural analysis framework. Three cultural perspectives, namely Integration, Differentiation, and Fragmentation are used to explain how culture is conceptualised and how cultural environments are described. The alignment of Smircich's paradigms with Martin's concept of cultural perspectives will assist in interpreting cultural environments and the outcomes of cultural analysis.

\begin{tabular}{|c|c|c|c|}
\hline Martin $(1992,2002)$ & Smircich (1983a) & $\begin{array}{c}\text { Willmott (1997) } \\
\text { Knights \& Willmott } \\
(1987) \\
\text { Alvesson (2002) }\end{array}$ & $\begin{array}{l}\text { Hofstede }(1998 \mathrm{a}) \\
\text { Schein }(2004,1993) \\
\text { Rousseau }(1990)\end{array}$ \\
\hline Cultural Perspective & tural $\mathrm{Pa}$ & Cultural Orientation & Cult \\
\hline Integration & & Technical & \\
\hline $\begin{array}{l}\text { Culture shared across } \\
\text { entire unit }\end{array}$ & $\begin{array}{l}\text { Culture as variable } \\
\text { (Functional }\end{array}$ & $\begin{array}{l}\text { Removal of formal } \\
\text { irrationality }\end{array}$ & $\begin{array}{l}\text { Artefacts (Symbols, } \\
\text { rituals, heroes) }\end{array}$ \\
\hline Differentiation & & Practical & Patterns of Behaviour \\
\hline $\begin{array}{l}\text { Culture shared by } \\
\text { parts of the unit }\end{array}$ & $\Downarrow$ & $\begin{array}{l}\text { Removal of } \\
\text { misunderstanding }\end{array}$ & $\begin{array}{l}\text { Behavioural Norms } \\
\text { Espoused Values }\end{array}$ \\
\hline $\begin{array}{l}\text { Fragmentation } \\
\text { Culture may or may } \\
\text { not be shared }\end{array}$ & $\begin{array}{l}\text { Culture as a root } \\
\text { metaphor } \\
\text { (Non-functional) }\end{array}$ & $\begin{array}{l}\text { Emancipatory } \\
\text { Removal of socially } \\
\text { unnecessary suffering }\end{array}$ & $\begin{array}{l}\text { Underlying Assumptions/ } \\
\text { Beliefs }\end{array}$ \\
\hline
\end{tabular}

Table 1 Cultural analysis of organisations: a synthesis and research framework

Gajendran et al. (2012) 'A conceptual approach to studying the organisational culture of construction projects', Australasian Journal of Construction Economics and Building, 12 (2) 1-26 
In Table 1, three types of cultural orientations outlined by Willmott (1997) and Alvesson (2002) are aligned with Martin's $(2002,2004)$ three perspectives of culture The three cultural orientations, namely Technical, Practical, and Emancipatory are used to explain how to manage or make meaning of cultural environments. The first orientation relates to the functional/variable paradigm while the last relates to the non-functional/metaphorical paradigm. Along with these cultural positions, differences also emerge in the manifestations used to decipher culture and the ontological/methodological approach taken to assess culture of project organisations (Hofstede 1998a; Schein 1993, 2004; Rousseau 1990).

\begin{tabular}{|c|c|c|c|}
\hline $\begin{array}{c}\text { Perspective/ } \\
\text { Attributes }\end{array}$ & Integration & Differentiation & Fragmentation \\
\hline$\frac{\text { Relationship to }}{\text { manifestation }}$ & $\begin{array}{l}\text { Consistency exists among } \\
\text { cultural manifestations. Various } \\
\text { levels in the hierarchy display } \\
\text { similar viewpoints. Culture is } \\
\text { monolith, integrated and } \\
\text { homogeneous }\end{array}$ & $\begin{array}{l}\text { Consistency and inconsistency } \\
\text { among cultural manifestations } \\
\text { exists at different levels. This } \\
\text { promotes differentiation and } \\
\text { diversity at group and individual } \\
\text { level. }\end{array}$ & $\begin{array}{l}\text { Lack of clarity of consistency } \\
\text { or inconsistency among } \\
\text { cultural manifestations. }\end{array}$ \\
\hline $\begin{array}{l}\text { Degree of } \\
\text { consensus }\end{array}$ & $\begin{array}{l}\text { Organisation wide consensus on } \\
\text { issues among all members of } \\
\text { the organisation. } \\
\text { Culture as shared across the } \\
\text { organisation }\end{array}$ & $\begin{array}{l}\text { Consensus exists within } \\
\text { subcultures but not between } \\
\text { them. } \\
\text { Culture as shared within } \\
\text { groups but not across an } \\
\text { organisation }\end{array}$ & $\begin{array}{l}\text { Issue-specific consensus } \\
\text { and confusion among } \\
\text { individuals. Overall lack of } \\
\text { consensus. } \\
\text { Culture unshared in the } \\
\text { organisation }\end{array}$ \\
\hline $\begin{array}{l}\text { Orientation to } \\
\text { ambiguity }\end{array}$ & $\begin{array}{l}\text { Excludes ambiguity. Culture is } \\
\text { defined in a way that denies } \\
\text { ambiguity. It assumes that } \\
\text { culture is about agreements } \\
\text { because values are shared. }\end{array}$ & $\begin{array}{l}\text { Channels ambiguity to outside } \\
\text { subculture. Culture is often } \\
\text { emphasised by disagreements. }\end{array}$ & $\begin{array}{l}\text { Acknowledges ambiguity. } \\
\text { Ambiguity is accepted as } \\
\text { inevitable and continues. It } \\
\text { is part of the usual way of } \\
\text { doing business. }\end{array}$ \\
\hline $\begin{array}{c}\text { Perspectives/ } \\
\text { Attributes }\end{array}$ & Integration & Differentiation & Fragmentation \\
\hline $\begin{array}{c}\text { Orientation/ } \\
\text { Attributes }\end{array}$ & Technical & Practical & Emancipatory \\
\hline Focus & $\begin{array}{l}\text { The focus is to identify and } \\
\text { manipulate cultural variables to } \\
\text { generate the intended culture. }\end{array}$ & $\begin{array}{l}\text { The focus is to generate and } \\
\text { interpret symbolic } \\
\text { communication to assist cultural } \\
\text { understanding }\end{array}$ & $\begin{array}{l}\text { The focus is to expose } \\
\text { domination and exploitation } \\
\text { aspects of a culture }\end{array}$ \\
\hline Process & $\begin{array}{l}\text { The emergence/ management of } \\
\text { culture is influenced by a } \\
\text { 'Calculation' process that } \\
\text { enhances prediction and control }\end{array}$ & $\begin{array}{l}\text { The emergence/ management of } \\
\text { culture is influenced by an } \\
\text { 'Appreciation' process that } \\
\text { improve mutual understanding }\end{array}$ & $\begin{array}{l}\text { The emergence/ } \\
\text { management of culture is } \\
\text { influenced by a } \\
\text { 'Transformation' process } \\
\text { that develops more rational } \\
\text { social relations }\end{array}$ \\
\hline Outcome & $\begin{array}{l}\text { The outcome of this orientation } \\
\text { is the removal of formal } \\
\text { irrationality in organisations }\end{array}$ & $\begin{array}{l}\text { The outcome of this orientation } \\
\text { is the removal of } \\
\text { misunderstanding }\end{array}$ & $\begin{array}{l}\text { The outcome of this } \\
\text { orientation is the removal of } \\
\text { socially unnecessary } \\
\text { suffering }\end{array}$ \\
\hline $\begin{array}{c}\text { Orientation/ } \\
\text { Attributes }\end{array}$ & Technical & Practical & Emancipatory \\
\hline
\end{tabular}

Figure 2 Three philosophical positions on culture: A snapshot

(Martin 1992, 2002; Willmott 1997; Alvesson 2002)

The cultural analysis framework presented in this study linking the three cultural perspectives (Martin 2002) to manifestations (Denison 1996; Hofstede et al. 1990; Schein 1990) and to paradigms (Alvesson 2002; Smircich 1983a) provides a comprehensive basis to analyse culture. This framework can be employed to study a cultural situation whereby the cultural environment is conceptualised through harmony (integration), conflict between groups (differentiation) and webs of ambiguity, paradox, and contradiction (fragmentation). Conceptual blind spots in each of these perspectives on culture (for example, the integration view is blind to ambiguities, and the fragmentation and differentiation views are blind to that 
which most cultural members share) are dealt with when a study is approached with a combination of all three perspectives (Martin 2002). Figure 2 (an elaboration of Table 1) summarises the essence of the cultural descriptions attributed to the three cultural perspectives, while linking them to cultural orientations. The following discussion compares and contrasts the alternative philosophical positions and synthesises a cultural analysis framework.

The above conceptualisation of culture can also assist in designing the empirical component of a study. This can assist in developing research instruments (e.g. survey questions, observations, and interview) by identifying the boundaries of theoretical constructs and the sample selection by identifying the members and physical scope of the units of analysis. Moreover, these conceptualisations can assist in identifying the appropriate blend of methods to study the relevant constructs.

This framework could enable researchers to contextualise their research direction and practicing managers to contextualise the proposed solutions to problems. It is argued that all three philosophical positions identified in the framework play a role in finding practicable solutions to construction industry problems (see Gajendran and Brewer 2007). The following section characteristics of project organisations as a base to discuss the application of the cultural analysis framework to study culture in construction.

\section{The Integration-Technical Philosophical Position}

Although studies in construction culture have not argued for an explicit unitary project culture, they do seek to develop and extend shared culture by the way of focusing on integration within organisations. Researchers have assumed this position in an attempt to remove irrationalities in the construction process and seek improved project outcomes. Both in construction (e.g. Baiden, Price \& Dainty 2006; Dainty, Briscoe \& Millett 2001a; London 2008; Winch 1989, 2001; Winch, Ushani \& Edkins 1998) and mainstream literature (e.g. Berggren, Soderlund \& Anderson 2001), there is a focus on the need for greater integration across project organisations to deal with fragmentation. These studies generally focus on coordination and monitoring of the diverse groups of participants and their operations in a construction project, proposing systems to monitor the progress made towards the achievement of the stakeholders' goals. Moreover, they suggest that shared expertise is a key characteristic of an integrated team, promoting free sharing of information among different units and developing the ability to predict project time and costs accurately. Therefore, integration-technical position is assumed in studies that focus on fragmentation within teams, firms and across project supply chains, in order to promote aligned and improved project outcomes.

\section{Integration Perspective}

The 'integration' perspective belongs to the functional paradigm. It seeks to understand the shared cultural manifestations in an organisation that hold it together, i.e. the 'glue' that holds different and diverse groups together in an organisation (Alvesson 2002). Therefore, 'Integrated' perspectives favour definitions of culture that view cultural manifestations as shared across an organisation/unit in its entirety, where ambiguity is non-existent or ignored. From this perspective, culture is considered as something that is shared by, or is unique to, a given group or organisation. The opposing 'fragmentation' perspective, belonging to the non-functional paradigm, argues that organisations, by nature, are paradoxical, hindering development of a unitary shared culture. It assumes that organisations cannot exist without ambiguity and that any ambiguity should not be ignored.

In many studies that support an integration view, culture is associated with peoples' customary behaviour and their habitual ways of seeing the world (Wilkins 1983; Schein 2004). In this way, Schein (2004, p. 17) characterises culture as 
a pattern of shared basic assumptions that was learned by a group as it solved its problems of external adaptation and internal integration, that has worked well enough to be considered valid and, therefore, to be taught to new members as the correct way to perceive, think, and feel in relating to those problems.

Schein $(1984,1993,2004)$ further suggests that groups learn culture by forming 'shared assumptions'; they solve problems through interpreting and acting upon the environment while integrating internal operations. In a similar vein, Wilkins (1983, p. 26) proposes

\begin{abstract}
culture primarily as the 'givens' or the taken-for-granted and shared assumptions that people make about how work is to be done and evaluated and how people relate to one another (...) the way we see the world is applied unthinkingly as the underlying assumptions develop, and most others in the organization or the unit also apply it in the same manner - so it does not get challenged.
\end{abstract}

Davis $(1984$, p.1) further argues culture is 'the pattern of shared beliefs and values that give members of an institution meaning, and provide them with the rules for behaviour in their organization.'

In essence, any idealistic organisational integration studies will be rooted in the belief that a project organisation should develop a shared understanding aiming for a unitary culture, implying that the lack of such shared understanding is a problem. It is argued that supporting integration in organisations, through modifying rules of behaviour will deliver strong cultures that enhance organisational profitability (Kotter \& Heskett 1992; Peters \& Waterman 1982; Denison \& Mishra 1995; Latham 1994; Egan 1998). Although the integration perspective, in terms of a unitary culture, is not widely endorsed by cultural researchers, using tools to manage cultures for enhanced performance is popular.

\title{
Culture-Performance Link
}

Most of the proponents of the integration perspective propose that culture can be used as a 'tool' to improve the performance of an organisation. Some argue that many of these studies use outer layers of cultural manifestations (refer Figure 1) to interpret culture (Simircich 1983, Alvesson 2002). For example, Deal and Kennedy (1988) focus on interpreting the shared espoused values of top management (e.g. mission statements) and Ouchi (1981) focuses on studying the shared formal or informal practices such as communication or decision-making. Popular literature on organisational culture in the 1980s generally subscribes to this integration perspective, relating ostensible artefacts, symbols and stories to the generation of organisation-wide consensus of cultures and values (Barley 1983; Schein 1984; Martin 2004; Schein 2004). Significant proportions of cultural studies relating to project organisations also make culture-performance links (see Cheung, Wong and Wu 2011; Ankrah, Proverbs and Debrah 2009; Andersen 2003; Zhang and Liu 2006; Baiden and Price 2011).

The unconscious attraction to adopt the 'integration' perspective in project cultural studies resonates from the argument for more integrated projects, which is closely associated to achievement of performance gains. Moreover, the position that culture is controllable and can be manipulated for performance gains, conforms to the popular view and offers the appeal of tangible outcomes from cultural studies.

\section{Some Critiques of Integration Perspective}

In synthesis, the integration perspective may employ varying 'cultural manifestations' to decipher culture. However, its essence is in the consistency of cultural manifestation and the consensus about basic beliefs among the members of the group. There is also a tendency to focus on the leaders of the group as the creators and interpreters of the group's culture (Schein 1983; Meyerson \& Martin, 1987). Alvesson (2002) argues that the integration 
perspective has a bias towards the positive functions of culture, that culture is controllable and has causal links to organisational performance.

The image of organisations presented in an integration perspective (an image of organisation-wide harmony and homogeneity) is difficult to sustain, given the prevalence of real-life paradoxes, inconsistencies, disruptions, conflicts and ambiguities in contemporary organisations (Martin 2004; Meyerson 1991 a \& b). Indeed, one of the key criticisms of this perspective is the linear approach it takes to framing culture; including an over-reliance on symbols as functional elements of the organisation and the use of moral judgement to identify 'good' and 'bad' cultures (Alvesson 2002). The integration perspective views any deviation from the ideal culture as a problem, which needs to be fixed. It is argued that inconsistencies (or subcultures) exist due to poor communication and, therefore, all that is required to remedy the lack of integration is a clear, shared understanding of the organisation's vision/mission, careful supervision and a better performance measurement regime.

The critiques of integration are overshadowed by the 'fragmentation perceptive' that evades moral judgements on culture and acknowledges paradoxes and ambiguity as an integral part of organisations. Of course, not all integration studies deny deviation from the unitary culture (see Wilkins 1983; Schein 2004) and they take an intermediate position between integration and fragmentation- the 'differentiation' perspective. Some cultural studies in project management (e.g. Ankarah and Langford 2005) favour the 'differentiation' perspective by focusing on sub cultures. Although they shy away from arguing for a unitary culture within an entire organisation, they may assume unitary culture within each sub culture.

\section{Technical Orientation to Culture}

The intention of a technical orientation is to fulfil the role of rational instrument to enhance prediction and control of functions in an organisation. This orientation focuses on the identification and manipulation of variables that are perceived to impact on an organisation's performance (Martin 2002; Alvesson 2002; Willmott 1997). Therefore, most of the 'technically-oriented' literature on culture is optimistic, believing that managers can control the values of their subordinates to achieve effective behaviour-viewing culture as a resource for effective managerial action. For example, Ouchi and Wilkins (1985, p. 462) observed that organisations use the integrated notion of culture as a rational instrument to solve problems. Therefore, culture is designed by senior management to profile the employees to fit the organisation's espoused values. Willmott $(1997)$ states that the 'technical' cognitive orientation is based on 'empirical-analytic science', one that removes all aspects of formal irrationality from organisations, denies ambiguity and seeks to develop organisation-wide shared understanding. The expected outcome of 'technically' orientated intervention is to create an integrated culture. Therefore, the technical orientation aligns with the integration perspective. Although cultural studies in organisations do not explicitly assume technical orientation, their approach to culture is influenced by removal of irrationality (see Young and Pheng 2008; Wong, Wong and Heng 2007; Höök and Stehn 2008; Price and Chahal 2006).

\section{Argument for the Integration-Technical Philosophical Position}

Although studies in construction culture have not argued for an explicit unitary project culture, they do seek to develop and extend shared culture by the way of focusing on integration within organisations. Researchers have assumed this position in an attempt to remove irrationalities in the construction process and seek improved project outcomes. There is a focus on the need for greater integration across project organisations to deal with fragmentation in both construction (e.g. Baiden, Price \& Dainty 2006; Dainty, Briscoe \& Millett 2001a; London 2008; Winch 1989, 2001; Winch, Ushani \& Edkins 1998) and mainstream literature (e.g. Berggren, Soderlund \& Anderson 2001). These studies generally focus on coordination and monitoring of the diverse groups of participants and their

Gajendran et al. (2012) 'A conceptual approach to studying the organisational culture of construction projects', Australasian Journal of Construction Economics and Building, 12 (2) 1-26 
operations in a construction project, proposing systems to monitor the progress made towards the achievement of the stakeholders' goals. Moreover, they suggest that shared expertise is a key characteristic of an integrated team, promoting free sharing of information among different units and developing the ability to predict project time and costs accurately.

\section{The Differentiation-Practical Philosophical Position}

\section{Differentiation Perspective}

The differentiation perspective, unlike the integration perspective, accepts some level of diversity (in shared assumptions, or consensus) in the member groups of an organisation. That is, cultural manifestations are shared within sections of an organisation. Therefore, the emerging cultural environment is 'differentiated'- an intermediate philosophical position between 'integration' and 'fragmentation' perspectives.

Consequently, 'differentiated' perspectives favour definitions in which cultural manifestations are shared within parts of an organisation (e.g. departments, groups etc.) and are unitary within those units/groups. In this perspective, ambiguity is acknowledged but confined to the subgroups (e.g. Smircich 1983b; Denison 1996; Mills 1988; Schein 1996; Martin 2002). For example, Denison (1996) suggests that values, beliefs and assumptions are the roots for the deep structure of organisations. Meanings are established through socialisation that produces a symbolic world. This leads to the stable or fragile nature of culture based on the cognition and action of individuals. Mills (1988) supports this view and suggests culture in an organisation is based on defined conditions, which could foster contradictions and conflict among segments. Each segment, however, develops a shared understanding of the cultural manifestations. Smircich, (1983b p.56) suggests culture is shared within a group based on how they develop a worldview:

In a particular situation the set of meanings that evolves gives a group its own ethos, or distinctive character, which is expressed in patterns of belief (ideology), activity (norms and rituals), language and other symbolic forms through which organisation members both create and sustain their view of the world and image of themselves in the world. The development of a worldview, with its shared understanding of group identity, purpose, and direction is a product of the unique history, personal interactions, and environmental circumstances of the group.

The differentiation perspective also acknowledges cultural variations within an organisation through growth or new ventures, and engagement with groups who are geographically dispersed and technically/functionally varied. Therefore, as the age and size of the organisation grows, or makes connections with outer entities, differentiation occurs (Gregory 1983). This view argues for the recognition of subcultures; however, it holds that subcultures have unitary or consistent shared understanding. Schein (1990, p. 117) describes this perspective as follows:

(...) once the group has many subcultures, its total culture increasingly becomes a negotiated outcome of the interaction of its subgroups. Organisations then evolve either by special efforts to impose their overall culture or by allowing dominant subcultures that may be better adapted to changing environmental circumstances to become more influential.

Clearly, it is difficult to establish whether this perspective falls directly under the functional or non-functional paradigm, as research from both the integration (functional) and fragmentation (non-functional) paradigms acknowledge aspects of the differentiation paradigm, with some restrictions. The differentiation paradigm offers pragmatism pragmatic position in enabling researches to position their study between the extreme ideological views (that is 'integration' and 'fragmentation'). 


\section{Boundaries and Subcultures in the Differentiation Perspective}

The differentiation perspective promotes the view that organisations are generally composed of a diverse set of subcultures that share some integrating elements of a dominant culture. The mix of sub cultures will depend on the nature of the environment in which the organisation operates and its internal composition (Martin, Sitkin, and Boehm, 1985). In this view, an organisation is described as a collection of subcultures based on arbitrary boundaries. These boundaries, from a cultural point of view, are not defined in legal or formal terms but are based on identification, interaction and the development of shared meaning and ideas (Alvesson 2002).

The commonly used boundaries in cultural studies are physical location (e.g. head office, site, precast yard, etc.) and bodies (people are embodied with culture and they carry it) (Santos \& Eisenhardt 2005; Moore \& Dainty 2001). Parker (2000) sees the origin of subcultures in different sources: spatial/functional (geographical location of work function), generational, (age and length of time in the organisation) and occupational/professional training.

Hofstede (1998b), Schein (1993) and Jones (1983) identify a number of sub cultural classifications. Schein (1996) characterises three types of subcultures, namely: operator, engineer, and executive and discusses the tensions between them. Hofstede (1998) identify three sub cultures, namely professional, administrative, customer interface, along the six dimensions (Process vs. results, employee vs. job, parochial vs. professional, open vs. closed, loose vs. tight, normative vs. pragmatic). The three subcultures discussed by Jones (1983) include product, bureaucratic and professional. Kumaraswamy et al. (2002) identified organisational, operational, professional and individualistic sub-cultures in the context of construction project organisations (c.f. Ankrah, Proverbs and Debrah 2009).

According to Meyerson (1994) different professions generate distinct ideologies due to the embodiment of different cognitive and symbolic systems producing different rules, conventions and meanings. The ideologies and approaches of the different professional subsystems come into contact when they work interdependently within organisations and as the actions and interpretations of their members negotiate and create order. As behaviours, interpretations, and justifications become adopted, they create an order that constitutes the particulars of that subculture, which reconstitutes the institutional system in a particular time and context. This explains the dynamic and complex sub-cultural taxonomies that emerge in construction organisations.

Martin (2002) argues that some literature assumes that the boundaries of a collective coincide with the boundaries of a culture. For example, an organisation's culture is coincident with the boundaries of that organisation. However, this view is considered to be problematic as most collectivities may be holding boundary roles, temporary or virtual roles, etc. In the context of a project, boundaries of architectural, engineering, quantity surveying and contracting firms and their cultures may not provide a clear separation on how their cultures engender the culture of a project organisation. The virtual communication does, to some extent, express a culture without bodily contact between group members. Moreover, temporary workers also violate traditional assumptions concerning subcultures in organisations, displaying an ambivalent relationship to the project and the associated organisation(s) (Usdiken, Soxen \& Enbiyaoglu 1988). Evidently, the boundaries of cultures and project organisations cannot be simply equated or clearly defined; boundaries need to be viewed as dynamic and changing.

In effect, boundaries have significant impact on emergent sub cultures in project organisation, at least from professional (see Ankarah 2005; Liu, Fellows and $\mathrm{Ng} \mathrm{2004}$; Akiner and Tijhuis 2007, operational (see Lansley and Riddick 1991), and geographical boundaries (see Bony 2010; Pheng and Yuquan 2002; Toor and Ogunlana 2008). In

Gajendran et al. (2012) 'A conceptual approach to studying the organisational culture of construction projects', Australasian Journal of Construction Economics and Building, 12 (2) 1-26 
addition, the temporary nature of project organisations elevates the tendency for more dynamic and transient boundaries (Turner and Muller 2003; Turner 2006). The emergence of new and hybrid procurement arrangements generates different natures of boundaries in each project, specifically from an operational point of view. Ultimately the inherent nature of the project environment poses significant challenges in developing a coherent and static understanding of sub cultures, pointing cultural studies towards the fragmentation perspective.

\section{Ambiguity and Conflict in Differentiation}

Earlier discussion on boundaries highlighted the acknowledgement of the presence of inconsistencies as well as consistencies in cultural manifestations among sub cultures. Therefore the differentiation perspective does not totally deny ambiguity in project organisations. Instead, it channels ambiguity and conflict to subcultures, so that each subculture responds to a small part of the organisational complexities and uncertainties. The differentiation view acknowledges that subcultures may conflict with the dominant organisational culture or may be orthogonal to a dominant culture, reflecting differences in functional, national, and occupational or project affiliations.

A 'conflict and claims culture', partly arising from ambiguity, is an area that has concerned the construction sector. Most studies channel conflicts arising from ambiguities to sub cultures: such as client, contracting, quantitative surveying, estimator sub cultures (see Rooke, Seymour and Fellows 2003; Loosemore 1999a; Ankrah and Langford 2005). The ambiguity focus of these studies remains on those sub-cultural aspects that are ostensible. Research assuming differentiation perspective is not too far removed from the oversimplifications of the integration perspective. Consistency and clarity still predominate within a culture, and ambiguity is only prevalent among subcultures.

In essence, the differentiation perspective in cultural studies arises from the view that cultural manifestations are shared within subgroups, but shared among partly among the groups. Therefore, cultures are not considered monolithic, but are treated as a collection of subcultures (Martin 2004; Schein 2004; Ankrah, Proverbs and Debrah 2009). In the differentiation view, multiple sources influence culture generation rather than an individual leader, as in the integration view. This creates multiple subcultures that share common histories or assumptions within an organisation (Martin 2004). Studies on the differentiation perspective have revealed that in an organisation, tensions could exist between subsystems of subcultures; for example: managers versus site workers, young versus older workers, consultants versus contractors, contractors vs. sub-contractors (Awakul and Ogunlana, 2002).

The attraction to adopt this perspective in cultural studies resonates from the argument for managing boundaries and national/professional cultures for enhanced project understanding. More specifically, to deal with conflicts (that may arise from ambiguity) between different groups of members in project organisations- that is to deal with different sub-cultures. The belief that sub-cultures are controllable and can be manipulated for aligning the interests of the project organisation, offers the appeal of tangible outcomes from cultural studies, as in the integration studies. However, the nature of the project organisational environment, particularly the complex transient boundaries and uncertainties, advocates conceptualising culture of organisations from the fragmentation perceptive. Although, extreme non-functional fragmentation studies do not believe in the existence of any form of shared culture within organisations, most studies shy away from this extreme stance.

\section{The Practical Orientation to Culture}

The 'practical orientation' to culture does not take an optimistic view of culture as technical orientation. Moreover, it does not advocate that managers can control the values of their

Gajendran et al. (2012) 'A conceptual approach to studying the organisational culture of construction projects', Australasian Journal of Construction Economics and Building, 12 (2) 1-26 
subordinates to achieve effective behaviour (Alvesson 2002). By acknowledging misunderstanding, this orientation accepts ambiguity and intends to remove it through symbolic communication. This non-functional orientation to culture contests the idea that management effectiveness can be attained through cultural manipulation and emphasises the importance of generating a more holistic understanding and reflection of an organisation's life. By assuming this emphasis, a 'practical orientation' to studying organisations involves observing and interpreting organisations through 'appreciation' rather than 'calculation' (Willmott 1997). This orientation, therefore, aligns with the 'differentiation' perspective on culture (Martin 2002).

In the differentiation perspective ambiguity is acknowledged, but confined to the subgroups and sub cultures (Martin 2004). Here, meanings are established through socialisation that produces a symbolic world and leads to the stable or fragile nature of culture that fosters contradiction and conflict among subcultures. The aim of the practical orientation is, 'to achieve common interpretations of situations [for] coordinated action' (Smircich 1983a, p. 351) and associates closely with removing misunderstanding among sub cultures in an organisation to achieve coordinated action. The 'practical' orientation recognises and appreciates 'questions of interpretation and description' and explores the inter-subjective experience of organisation thus removing unnecessary misunderstandings in organisations. Practical orientation, addressing communication issues to improve information flows (and thereby attempting to reducing misunderstanding), is widely adopted in construction project management (see Phua and Rowlinson 2003; Loosemore and MusImani 1999; Ochieng and Price 2010).

\section{Argument for the Differentiation/Practical Cultural Position}

Research assuming this position focuses on improving communication in the construction process and to minimise misunderstandings. Studies acknowledging the elusiveness of total integration and aiming for partial integration with selected firms, tiers, or groups that fall into this cultural position. This position can be argued for studies dealing with (e.g. professional, trade, informal groups) sub-culture of groups, lack of collaboration and trust among groups and those seeking understanding of communications between different sub-cultures (Ankrah, and Langford, 2005; Loosemore and MusImani, 1999). These studies can assist in improving understanding between sub-cultures that lead to conflict mitigation and enhanced project collaboration.

\section{The Fragmentation-Emancipation Philosophical Position}

\section{Fragmentation Perspective}

The third key perspective of organisational culture studies is 'fragmentation' (Martin et al. 1983; Meyerson and Martin 1987; Martin, 2004). This approach views culture as a disorder that contributes to dysfunctional aspects in organisational life-thereby, this approach aligns with the 'non-functional' cultural paradigm (Alvesson 1993b, 2002; Meyerson 1991a, 1991b; Feldman 1991). The fragmentation perspective accepts ambiguity, rather than denying or channelling it, and views organisational culture as inherently ambiguous leading to 'fuzziness' in organisational life (Meyerson, 1991a, 1991b; Alvesson 1993b; Sveningasson \& Alvesson 2003).

The fragmentation approach to culture is described aptly by Meyerson (1991a p. 256) who notes that 'culture was the code word for the subjective side of organisational life (...) its study represented an ontological rebellion against the dominant functionalist or 'scientific' paradigm".' Ignoring this perspective in organisational studies according to Meyerson (1991b) means 'to dismiss the [informalities and] ambiguities in favour of strictly what is clear and shared. [This] is to exclude some of the most central aspects of the members' cultural experiences and to ignore the essence of their cultural community' (p. 131-132). Recent literature in construction management has raised attention to the subjective informal,

Gajendran et al. (2012) 'A conceptual approach to studying the organisational culture of construction projects', Australasian Journal of Construction Economics and Building, 12 (2) 1-26 
aspects of project organisations (see Chan \& Raisanen 2009; Marrewijk 2008), highlighting the potential of such a perspective in developing a better understating of project organisations. Meyerson (1991b, p.131-132) argues that, in reality:

\begin{abstract}
( ...) members do not agree upon clear boundaries, cannot identify shared solutions, and do not reconcile contradictory beliefs and multiple identities. Here culture is characterised as a web, where individuals are nodes in the web-temporarily connected by shared concerns to some nodes and not to others. When a particular issue comes to the surface, certain nodes and patterns of connections become relevant. The emerging patterns of connection in an organisation will consist of agreements, disagreements, and ignorance. Most importantly, from this perspective the inherently active and dynamic nature of culture is made apparent.
\end{abstract}

The characteristics of project organisations resemble some of the above features. Particularly, construction projects are characterised as loosely coupled systems with transient boundaries. In each project a web of temporarily connected organisations forms a project organisation to deliver a product or service (see Turner and Muller 2003; Dubois, and Gadde, 2002). Although members of organisations are connected via a transient web, they believe they belong to a culture. Meyerson (1991b, p.131-132) also argues that organisations:

(...) share a common orientation and overarching purpose, face similar problems [e.g. project goals- delivering a project within the established cost and timeframe with desired quality, while making profits], and have comparable experiences. However, these shared orientations and purposes accommodate different beliefs and incommensurable technologies, these problems imply different solutions, and these experiences have multiple meanings (...) Thus, for at least some cultures, to dismiss the ambiguities in favour of strictly what is clear and shared is to exclude some of the most central aspects of the members' cultural experienced and to ignore the essence of their cultural community.

Primarily, Meyerson's view is that organisational members do not necessarily display a high level of shared understanding, but can still share cultures through common orientations and purposes which accommodate different beliefs and ambiguities. Unlike the 'integration' perspective, awareness of ambiguity is not experienced as a temporary stage during an organisational change process; rather, ambiguity is seen as a permanent state- - the way things are'. It is argue that this perspective adds a sound basis to cultural analysis of organisations by acknowledging ambiguities could be inherent and perpetual in organisations (Meyerson \& Martin, 1987; Martin 2002; Alvesson 2002). Therefore, cultural manifestations are not necessarily shared across or within sections of the organisation, creating a cultural environment that is 'fragmented'. The approach fundamentally challenges the dominant idea that a culture (subculture) is a clear and known entity that creates unity and harmony within an organisation (or a group within it). In this perspective, irreconcilable interpretations are simultaneously entertained, paradoxes are embraced and the lack of a shared/integrated set of values is accepted as normal.

Here, relationships between manifestations are characterised by a lack of clarity caused by ignorance or complexity. Any attempt to design organisational processes to resolve irreconcilable conflicts in organisations is regarded as a temporary and superficial 'smoke screen'. The confusion emanating from inconsistent viewpoints and disagreements makes it difficult to draw cultural and subcultural boundaries. The boundary around the organisation then becomes amorphous and permeable, as various 'feeder' cultures from the surrounding environments fade in and out of attention (Martin 2002).

The difficulty in articulating the ever-changing patterns and ambiguities of culture makes the fragmentation perspective the most difficult to conceptualise (Martin 2002). Fragmentation

Gajendran et al. (2012) 'A conceptual approach to studying the organisational culture of construction projects', Australasian Journal of Construction Economics and Building, 12 (2) 1-26 
studies see ambiguity as the defining feature of cultures in organisations. As such, Martin (2004) argues that understanding ambiguities should be the central component of any study of culture. However, the very nature of the fragmentation approach has resulted in very few researchers adopting it as a framework for organisational studies, due to its emphasis on uncertainty, contradiction and confusion and for acknowledging that some ambiguities cannot be eliminated (Martin 2004). Those who embrace the fragmentation perspective could argue the interpretations of the recommendations proposed by industry reviews (e.g. Latham 1994 and Egan 1998), in terms of embracing integration by controlling, manipulating and predicting cultures to address construction industry issues, is fundamentally flawed. This does not mean cultures cannot be changed. Here, cultures are transformed via emancipation that liberates members from exploitation by making them aware of their traditionally held unconscious values. Therefore, this perspective discredits the practice of manipulating and controlling cultures.

\section{Defining Ambiguity and Sources of Ambiguity}

In organisations and projects, managers frequently emphasise an informal, family-like community spirit. However, everyday practices and relationships often deviate from this ideal (Alvesson 1990). In most instances, the term 'organisational culture' conjures the image of an organisation as being:

typically unitary and unique, characterized by a stable set of meanings (...) arguably [however] cultural manifestations are far from always neatly organized, values not easily ranked and cultural ideas may be unsystematic and incoherent.(Alvesson 2002, p. 145)

Meyerson (1991a) argues that in some cultures, boundaries are not agreed, shared solutions are non-existent, and members do not reconcile contradictory beliefs and multiple identities. This leads to lack of clarity in organisations with ambiguity as a figure (or antifigure) that emerges from this context. Two types of ambiguities are identified in the literature, arising from:

- a lack of clarity - whereby ambiguity is felt as an internal state and occurs due to the absence of information - once the information is available it vanishes; e.g. incomplete drawings/specifications could lead to ambiguity with respect to how a detail should be constructed. This kind of ambiguity is removed when the required information becomes available. However, not supplying the information within a reasonable period of time could lead to conflict and subsequent litigation (Meyerson, 1990; Meyerson \& Martin, 1987).

- irreconcilable contradictions - in which ambiguity is the result of conflicts between individuals (or groups) which embrace two or more meanings that are irresolvable. E.g. irresolvable contradictions could emerge when a client and contractor attach different meaning to a product, process or situation (Meyerson, 1990; Meyerson \& Martin, 1987).

In organisations, there is both unity and division in work relations depending upon the complexity of the surrounding environment, group membership and the degree of ambiguity in organisational rules and policies (see Ankrah, and Langford, 2005). Although the fragmentation perspective is considered to be important, some researchers question the extensive use of this perspective, as fragmentation could be interpreted as no culture in an organisation (Alvesson 2002).

One could argue that fragmentation could be one of the perspectives for exploring cultures in organisations in the construction industry. However, construction organisations are underexplored from this perspective. Adoption of this perspective could provide a meaningful approach to understand culture in construction. 


\section{The Emancipatory Orientation}

The 'emancipatory' cognitive interest is based on 'critical science' and intends to develop more rational social relations through realisation (Alvesson 2002; Knights \& Willmott 1992; Willmott 1997). The focus of this mode is the exposure of domination and exploitation, therefore, it takes a 'transformation' orientation. That is, it endeavours to make members of a group aware of the emancipatory approach to investigate the negative features of organisational life and to develop an understanding of, and to counteract, the taken-forgranted beliefs and values that exploitation and domination that characterise relationships in their culture, while encouraging them to transform the way they operate.

One outcome of this mode of analysis concerns the removal of 'unnecessary suffering' in organisations (Willmott 1997). The main focus imposes limits on actions and interactions. This orientation provides insight into organisational life by grasping the traditional patterns and the repressive aspects of culture and may contribute to liberating the organisation from its traditional cultural environment. It includes understanding irreconcilable tensions between opposites, sometimes described as ironies, paradoxes, or contradictions (Martin 2002). Ambiguity studies, generally, view such occurrences as normal and salient, and part of the organisation's function.

This orientation, therefore, aligns with the 'fragmentation' perspective on culture in that ambiguity is acknowledged as an inherent part of an organisation, and views organisational culture as inherently ambiguous leading to 'fuzziness' in organisational life. Therefore, the organisations face contradictions and paradoxes (e.g. through information conflicts, un reasonable risk exposure) contributing to unnecessary suffering of members. Such suffering, from a construction point of view, includes the culture of claims, litigation, unsafe practices and other forms of exploitation etc. By liberating the members of the organisation from taken for granted assumptions, unnecessary suffering can be minimised.

Although the emancipatory approach does not relate to business results directly, it nevertheless, influences people in relation to their ways of constrained thinking and acting. Therefore, the purpose of emancipatory cultural studies is about liberating human potential or, more defensively, illuminating the obstacles to emancipation. Encouraging critical reflection on beliefs, values and understanding of social conditions becomes the prime task of this cultural orientation. This orientation is underexplored in construction project management.

\section{Argument for the Fragmentation-Emancipatory Cultural Position}

Clearly, when culture is discussed in the project literature, fragmentation is most often associated with transient boundaries, ambiguity and conflicts. However, studies of project organisations cultures based on a Fragmentation - emancipation position are not common in construction. The complex characterisation of culture along with no explicit link between project performance enhancements makes this perspective unattractive. Nevertheless, burgeoning interest can be sensed in certain elements of these approaches in studying issues such as conflicts (e.g. Awakul \& Ogunlana 2002; Loosemore, Nguyen \& Denis 2000; Rooke, Seymour \& Fellows 2003), disputes (e.g. Loosemore 1999a, 1999b), claims (e.g. Rooke, Seymour \& Fellows 2004), and general fragmentation emanating from industry structure, information and attitude (Marrewijk et al 2008).

This position does not believe that culture can be fully manipulated or controlled to achieve desired outcomes; rather cultures are transformed by emancipation. Change management literature suggests that managers are neither in total control of cultures nor without any influence for transforming cultures. Moreover, acknowledging that some of the initiatives to remove irrationality are smoke screens that are not sustained with time- but rather seek solutions acknowledging paradox and chaos can provide a new range of initiatives in project management. This means, empowering members of a culture to transform traditionally held

Gajendran et al. (2012) 'A conceptual approach to studying the organisational culture of construction projects', Australasian Journal of Construction Economics and Building, 12 (2) 1-26 
beliefs resulting in exploitative outcomes into new egalitarian beliefs producing coconstructed outcomes. There is a need for future cultural studies to explore this perceptive and to understand the process of cultural transformation in inherently fragmented organisational contexts.

\section{Contextualising Cultural Analysis in Construction Organisations}

This paper argues that cultural studies can adopt a single philosophical position or mix of positions. The characterisation of organisational issues to be studied is fundamental to identify a suitable cultural position(s) to conduct meaningful cultural studies. It is arguable that the worldview (e.g. objectivist-subjectivist) of the researchers/managers/authors characterise the way in which the organisational issues are approached. However, adopting the pragmatism view using multiple or mixed research methods (Creswell and Clark 2007) enable to maintain a balance among different ideologically extreme worldviews.

Construction organisations are inherently unique and fragmented- subjected to boundaries and multiple stakeholders (Lam et al. 2007; Rahman \& Kumaraswamy 2005; Gajendran 2010). The stakeholders play a critical role in characterising the culture: by having organisational goals that are not shared across the project organisation, stakeholders can create unnecessary boundaries between members and, thus, bring fragmentation (Usdiken, Soxen \& Enbiyaoglu 1988; Cox 1996; Cox \& Thompson, 1997; Walker \& Wing 1999; Dainty, Briscoe \& Millett 2001a, 2001b). Indeed, Hansfield and Nichols (1999) point to poor alignment of organisational cultures as the factor adversely affecting integration, a point broadly supported in the literature (see Baiden, Price \& Dainty 2006; Dainty, Briscoe \& Millett 2001a; Voordijk, Meijboon \& Haan 2006).

Studies into project organisations have proposed numerous initiatives for integration, to address the ills caused by fragmentation (see Latham 1994 and Egan 1998). Extensive focuses on removal of irrationality or manipulation of culture to improve performance may not yield the expected outcomes. By nature, construction project organisations are paradoxical and contradictory, generating ambiguity and leading to conflicts (Chan and Raisanen 2009; Marrewijk et. al. 2008). Such inherent characteristics of project organisations, e.g. paradoxes, boundaries, and ambiguity cannot be totally eliminated; rather, project organisations need to be studied and managed within those constraints. It is important to note that implementation of any initiatives or solutions to deal with fragmentation are also subject to the fragmentation of the construction industry- to some extent beyond the control of organisations. Not contextualising the cultural studies without appropriate acknowledgment to inherent fragmentation could lead to failed or ineffective outcomes. Therefore, with any integration initiative, due consideration needs to be given to the project characteristics that generate fragmentation, in order to facilitate more effective integration (or reduction of fragmentation) (Charoenngam et al. 2004; Chatman \& Jehn 1994).

\section{Conclusions}

Theoretical perspectives should drive project management practice as much as empirical enquiry. Although cultural studies have mobilised various methodological approaches in the project management domain, the point of departure for this research is that they have predominantly been conceptualised within the 'functional' paradigm, and driven by empirical inquiry. These approaches invariably treat culture as a feature of an organisation or project, which is amenable to conscious control and manipulation towards performative outcomes. Moreover, these offer limited flexibility by prescribing a singular philosophical position from which to observe culture. In contrast, by reviewing cultural studies literature as applied to organisations this paper has synthesised a robust theoretical platform for understanding the culture of projects and organisations. It concludes that when investigating cultural environments adopting the 'non-functional' paradigm: facilitates the better understanding of individuals' behaviour within group settings, therefore allowing project participant behaviour

Gajendran et al. (2012) 'A conceptual approach to studying the organisational culture of construction projects', Australasian Journal of Construction Economics and Building, 12 (2) 1-26 
to be contextualised within a temporary project organisation, and; provides a richer, more compelling explanation of project performance/outcomes as an emergent feature of the complex network of relationships that is inherent in project organisations.

This paper presents a conceptual framework that serves dual purposes. Firstly, it simplifies and guides the cultural analysis of organisations, providing a framework against which cultures can be defined, evaluated and understood. Secondly, it reveals the three philosophical perspectives (Integration, Differentiation, and Fragmentation) and three orientations (Technical, Practical and Emancipation), which necessarily underpin all cultural analyses. This paper suggests that a hybrid functional/non-functional cultural analysis framework will be more effective, allowing researchers and practicing managers to identify and operate from one or more possible positions. In this way they can embrace a pragmatic approach to the study of organisational cultures, using both positivist and subjectivist methods to obtain authentic outcomes.

\section{References}

Adriaanse, A. and Voordijk, H. (2005) 'Inter-organisational communication and ICT in construction project: a review using meta-triangulation', Construction Innovation, 5, 159-177

Alvesson, M. (1987) 'Organisations, culture and Ideology', International Studies of Management \& Organisations, VXII (3), 14-18

Alvesson, M. (1990) 'On the popularity of organisational culture', Acta Sociologica, 33 (1), $31-49$

Alvesson, M. (1993a) Cultural Perspectives on Organisations, Cambridge University Press, Cambridge

Alvesson, M. (1993b) 'Organisations as rhetoric: Knowledge-intensive firms and the struggle with ambiguity', Journal of Management Studies, 30 (6), 997-1015

Alvesson, M. (2002) Understanding Organisational Culture, SAGE Publications, London

Alvesson, M. and Willmott, $H$. (1992) 'On the idea of emancipation in management and organisational studies', The Academy of Management Review, 17 (3), $432-464$

Andersen, E S (2003) 'Understanding your project organisation's character', Project Management Journal, 34 (4), 4-11

Ankrah, N. A. and Langford, D. A. (2005) 'Architects and contractors: a comparative study of organisational cultures', Construction Management and Economics, 23 (6), 595-607

Ankrrah, N. A. Proverbs, D. and Debrah, Y. (2009) 'Factors influencing the culture of a construction project organisation: An empirical investigation' Engineering, Construction and Architectural Management, 16 (1), 26-47

Anumba, C. E. H. Dainty, A. Ison, S. and Sergeant, A. (2006) 'Understanding structural and cultural impediments to ICT systems integration: A GIS based case study', Engineering, Construction and Architectural Management, 13 (6), 2006

Awakul, P. and Ogunlana, S. O. (2002) 'The effect of attitudinal difference on interface conflicts in large scale construction projects: a case study', Construction Management and Economics, 20, 365-377

Baiden, B. K. Price, A. D. F. and Dainty, A. R. J. (2006) 'The extent of team integration within construction projects', International Journal of Project Management, 24, 13-26

Baiden, B. K. and Price, A. D. F. (2011) 'The effect of integration on project delivery team effectiveness', International Journal of Project Management, 29 (2), 129-136

Barley, S. R. (1983) 'Semiotics and the study of occupational and organisational cultures', Administrative Science Quarterly, 28, 393-413

Berggren, C. Soderlund, J. and Anderson, C. (2001) 'Clients, contractors, and consultants:

Gajendran et al. (2012) 'A conceptual approach to studying the organisational culture of construction projects', Australasian Journal of Construction Economics and Building, 12 (2) 1-26 
the consequences of organisational fragmentation in contemporary project environments' Project Management Journal, 32 (3), 39-48

Brochner, J. Rosander, S. and Waara, F. (2004) 'Cross-border post-acquistion knowledge transfer among construction consultants', Construction Management and Economics, 22 (4), 421-427

Burrell, G. and Morgan, G. (1979) Sociological paradigms and organisational analysis: Elements of the sociology of corporate life, Heinemann, London

Cameron, K. S. Quinn, R. E. and DeGraff, J. (2006) Competing Values Leadership: Creating Value in Organisations, Edward Elgar, Lancaster

Cameron, K. S. and Quinn, R. E. (2006) Diagnosing and changing organisational culture, CJossey-Bass, San Francisco

Chan, P. W. and Raisanen, C. (2009) 'Editorial: informality and emergence in construction', Construction Management and Economics, 27 (10), 907-912

Charoenngam, C. Ogunlana, S. O. Ning-Fu, K. and Dey, P. K. (2004) 'Re-engineering construction communication in distance management framework', Business Process Management Journal, 10 (6), 645-672

Chatman, J. A. and Jehn, K. A. (1994) 'Assessing the relationship between industry characteristics and organisational culture: How different can you be?', The Academy of Management Journal, 37 (3), 522-553

Cheng, E. W. L. Li, H. Love, P. and Irani, Z. (2004) 'A learning culture for strategic partnering in construction', Construction Innoation, 4 (1), 53-65

Cheung, S.O., Wong, P.S.P. and Wu, A.W.Y. (2011) 'Towards an organisational culture framework in construction', International Journal of Project Management, 29, 33-44

Coffey, V. (2010) Understanding organisational culture in the construction industry, Spon, London

Cooper, C. L. and Rousseau, D. M. (1999) The Virtual Organisation, Wiley, West Sussex

Cox, A. (1996) 'Relational competence and strategic procurement management', European Journal of Purchasing \& Supply Management, 2 (1), 57-70

Cox, A. and Thompson, L. (1997) 'Fit for purpose' contractual relations: determining a theoretical framework for construction projects', European Journal of Purchasing \& Supply Management, 3 (3), 127-135

Creswell, J. W. and Clark, V. L. P. (2007) Designing and conducting mixed method research, Thousand Oaks: Sage

Dainty, A. Green, S. and Bagilhole, B., Eds. (2007), People and culture in construction: A reader, Taylor \& Francis, Oxen

Dainty, D. R. J. Briscoe, G. H. and Millett, S. J. (2001a) 'New perspectives on construction supply chain integration', Supply Chain Management, 6 (3/4), 163-173

Dainty, D. R. J. Briscoe, G. H. and Millett, S. J. (2001b) 'Subcontractor perspectives on supply chain alliances', Construction Management and Economics, 19, 841-848

Daly, J. P. Pouder, R. W. and Kabanoff, B. (2004) 'The Effects of Initial Differences in Firms' Espoused Values on Their Post-merger Performance', The Journal of Applied Behavioral Science, 40 (3), 323-343

Davis, S. (1984) Managing Corporate Culture, Ballinger, Cambridge MA

de Bony, J. (2010) 'Project management and national culture: A Dutch-French case study', International Journal of Project Management, 28, 173-182

Deal, T. E. and Kennedy, A. A. (1988) Corporate cultures: the rites and rituals of corporate

Gajendran et al. (2012) 'A conceptual approach to studying the organisational culture of construction projects', Australasian Journal of Construction Economics and Building, 12 (2) 1-26 
life, Penguin Books, London

Denison, D. R. (1996) 'What is the difference between organisational culture and organisational climate? A native's point of view on a decade of paradigm wars', Academy of Management Review, 21 (3), 619-654

Denison, D. R. and Mishra, A. K. (1995) 'Towards a theory of organisational culture and effectiveness', Organisation Science 6 (2), 204-223

Dubois, A. and Gadde, L.-E. (2002) 'The construction industry as a loosely coupled system: implications for productivity and innovation' Construction Management and Economics, 20, 621-631

Egan, J. (1998) Rethinking Construction, Department of the Environment, London.

Feldman, M. S. (1991) 'The meaning of ambiguity: Learning from stories and metaphors', Peter J Frost, L. F. M., Meryl Reis Louis, Craig C Lundberg, Joanne Martin (Ed.), Reframing Organisational Culture, Sage. California, 145-164

Fellows, R. (2006) 'Understanding approaches to culture', Construction Information Quarterly, 8 (4), 159-166

Fellows, R. (2010) 'Book Review: Understanding Organisational Culture in the Construction Industry', Construction Management and Economics, 28 (8), 898-900

Gajendran, T. (2010) The role of Culture in the Integration of Information and Communication Technology (ICT) in construction projects, The University of Newcastle, Doctor of Philosophy, Newcastle, 469

Gajendran, T. and Brewer, G. (2007) 'Integration of information and communication technology: Influence of the cultural environment', Engineering, Construction and Architectural Management, 14 (6), 532-549

Geertz, C. (1975) The Interpretation of Cultures, Hutchinson, London.

Gregory, K. L. (1983) 'Native View Paradigms: Multiple cultures and culture conflicts in organisations', Administrative Science Quarterly, 28, 359-376

Hansfield, R. B. and Nichols, E. L. (1999) Introduction to supply chain management. Prentice-Hall, Englewood Cliffs NJ

Hartmann, A. (2006) 'The role of organisational culture in motivating innovative behaviour in construction firms', Construction Innovation, 6, 159-172

Hofstede, G. (1998a) 'Attitudes, values and organisational culture: Disentangling the concepts', Organisational Studies, 19 (3), 477-492

Hofstede, G. (1998b) 'Identifying organisational sub cultures: an empirical approach', Journal of Management Studies, 35 (1), 1-12

Hofstede, G. Neuijen, B. Ohayv, D. D. and Sanders, G. (1990) 'Measuring organisational cultures: A qualitative and quantitative study across twenty cases', Administrative Science Quarterly, 35 (2), 286-316

Hofstede, G. Hofstede, G. J. and Minkov, M. (2010) Cultures and organisations: software of the mind, McGraw Hill, London

Hofstede, G. (2001) Culture's consequences: Comparing values, behaviors, institutions and organisations across nations, $2^{\text {nd }} \mathrm{ed}$, Sage, Thousand Oaks

Höök, M. and Stehn, L. (2008) 'Applicability of lean principles and practices in industrialized housing production', Construction Management and Economics, 26 (10), 1091-1100

Jones, G. R. (1983) 'Transaction cost, property rights, and organisational culture: An exchange perspective', Administrative Science Quarterly, 28, 454-467

Kabanoff, B. Waldersee, R. and Cohen, M. (1995) 'Espoused values and organisational

Gajendran et al. (2012) 'A conceptual approach to studying the organisational culture of construction projects', Australasian Journal of Construction Economics and Building, 12 (2) 1-26 
change themes', Academy of Management Journal, 38 (4), 1075-1104

Knights, D. and Willmott, H. C. (1987) 'Organisational culture as management strategy: A critique and illustration from the financial services industry', International Studies of Management \& Organisations, 17 (3), 40-63

Kornelius, L., Wamelink, J.W.F (1998) 'Case Study: The virtual corporation learning from construction', Supply Chain Management, 3 (4), 193-202

Kotter, J. P. and Heskett, J. L. (1992) Corporate culture and performance, Maxwell Macmillan, New York.

Kumaraswamy, M., Rowlinson, S., Rahman, M. and Phua, F. (2002) 'Strategies for triggering the required 'cultural revolution' in the construction industry', in Fellows, R. and Seymour, D. (Eds), Perspectives on Culture in Construction, CIB Report, CIB, Shizuoka, 275

Lam, K. C. Want, D. Lee, P. T. K. and Tsang, Y. T. (2007) 'Modelling risk allocation decision in construction contracts', International Journal of Project Management, 25, 485-493

Latham, M. (1994) Constructing the Team, HMSO, London

Ling, F. Y. Y. Ang, A. M. H. and Lim, S. S. Y. (2007) 'Encounters between foreigners and Chinese: Perception and management of cultural differences', Engineering, Construction and Architectural Management, 14 (6), 501-518

Liu, A. and Fellows, R. (2008) 'Behaviour of quantity surveyors as organisational citizens', Construction Management and Economics, 26 (12), 1271-1282

Liu, A. Fellows, R. and Ng, J. (2004) 'Surveyors' perspective on ethics in organisational culture', Engineering, Construction and Architectural Management, 11 (9), 438-449

Loosemore, M. (1999a) 'Responsibility, power and construction conflict', Construction Management and Economics, 17, 699-709

Loosemore, M. (1999b) 'A grounded theory of construction crisis management', Construction Management and Economics, 17, 9-19

Loosemore, M. and Muslmani, H. S. A. (1999) 'Construction project management in the perian culf: inter-cultural communication', International Journal of Project Management, 17 (2), 95-100

Loosemore, M. Nguyen, B. T. and Denis, N. (2000) 'An investigation into the merits of encouraging conflict in the construction industry', Construction Management and Economics, 18, 447-456

Marrewijk, Av. (2007) 'Managing project culture: The case of Environ Megaproject', International Journal of Project Management, 25, 290-299

Marrewijk, Av. Clegg, S. R. Pitsis, T. S. and Veenswijk, M. (2008) 'Managing public-private megaprojects: Paradoxes, complexity, and project design', International Journal of Project Management, 26 (5), 591-600

Martin, J. (1992) Cultures in organisations: Three perspectives, Oxford University Press, New York

Martin, J. (2002) Organisational Culture: Mapping the terrain, Sage, Newbury Park, CA

Martin, J. (2004) Organisational culture, Research Paper Series, Stanford, Research Paper No 1847

Martin, J. Frost, P. J. and O'Neill, O. A. (2004) Organisational culture: Beyond struggles for intellectual dominance, Stanford Research Paper Series, No 1864.

Martin, J. Sitkin, S. B. and Boehm, M. (1985) 'Founders and the elusiveness of a cultural legacy', Frost, P. J. More, L. F. Louis, M. R. Lundberg, C. C. and Martin, J. (eds.), Organisational Culture, Sage. California, 99-124 
Meyerson, D. (1994) 'Interpretations of stress in institutions: The cultural production of ambiguity and burnout', Administrative Science quarterly, 39 (4), 628-653

Meyerson, D. and Martin, J. (1987) 'Cultural Change: An integration of three different views', Journal of Management Studies, 24 (6), 623-647

Meyerson, D. E. (1991a) Acknowledging and uncovering ambiguities in cultures, Frost, P. Moore, L. Louis, M. Lundberg, C. and Martin, J. (eds.), Reframing Organisational Culture, Sage. California, 254-270

Meyerson, D. E. (1991b) 'Normal' ambiguity? A glimpse of an occupational culture', Frost, P. Moore, L. Louis, M. Lundberg, C. and Martin, J. (eds.), Reframing Organisational Culture, Sage, California, 131-143

Mills, A. (1988) 'Organisation, gender and culture', Organisation studies, 9 (3), 351-370

Moore, D. R. and Dainty, A. R. J. (2001) 'Intra-team boundaries as inhibitors of performance improvement in the UK design and build projects: a call for change', Construction Management and Economics, 19, 559-562

Morgan, G. (1980) 'Paradigms, Metaphors and Puzzle solving in organisation theory', Administrative Science Quarterly, 605-622

Morse, J. M. and Richards, L. (2002) Readme First for a User's guide to Qualitative Methods, Sage Publications, California

Nielsen, J. (2007) 'Struggles for health and safety in the Danish construction Industry', International Journal of Occupational and Environmental Health, 13 (1), 21-27

O'Reilly, C. A. Chatman, J. and Cadwell, D. F. (1991) 'People and organisational culture: A profile comparison approach to assessing person-organisation fit', The Academy of Management Journal, 34 (3), 487-516

Ouchi, W. G. (1981) Theory Z: how American business can meet the Japanese challenge, Addison-Wesley, Reading

Ouchi, W. G. and Wilkins, A. L. (1985) 'Organisational Culture', Annual Review of Sociology, 11, 457-483

Parker, M. (2000) Organisational culture and identity, SAGE, London

Peters, T. J. and Waterman, R. H. (1982) In search of excellence: Lessons from America's best run companies, Hamper \& Row, New York

Pheng, L. S. and Yuquan, S. (2002) 'An exploratory study of Hofstede's corss-cultural dimensions in construction projects', Management Decision, 40 (1), 7-15

Price, A. D. F. and Chahal, K. (2006) 'A strategic framework for change management', Construction Management and Economics, 24, 237-251

Ochieng, E. G. and Price, A. D. F. (2010) 'Managing cross-cultural communication in multicultural construction project teams: The case of Kenya and UK', International Journal of Project Management, 28 (5), 449-460

Phua, F. T. T. and Rowlinson, S. (2003) 'Cultural difference as explanatory variable for adversarial attitudes in the construction industry: the case of Hong Kong', Construction Management and Economics, 21 (7), 777-785

Rahman, M. M. and Kumaraswamy, M. M. (2005) 'Assembling integrated project reams for joint risk management', Construction Management and Economics, 23, 365-375

Rooke, J. Seymour, D. and Fellows, R. (2003) 'The claims culture: a taxonomy of attitudes in the construction industry', Construction Management and Economics, 21 (2), 167-174

Rooke, J. Seymour, D. and Fellows, R. (2004) 'Planning for claims: an ethnography of industry culture', Construction Management and Economics, 22 (6), 655-662 
Root, D. (2005) 'Creating a culture of safety on construction sites', Risk management, 52 (11), 56-60

Rousseau, D. M. (1990) 'Assessing Organisational Culture: The Case for Multiple Methods', Goldstein, I. L. (Ed.), Frontiers of Industrial and Organisational Psychology, Jossey-Bass Inc, California

Ruikar, K. Anumba, C. J. and Carrillo, P. M. (2005) 'End-user perspective on use of project extranets in construction organisations', Engineering, Construction and Architectural Management, 12 (3), 325-343

Santos, F. M. and Eisenhardt, K. M. (2005) 'Organisational boundaries and theories of organization', Organisation Science, 16 (5), 491-508

Sathe, V. (1985) Culture and related corporate realities: texts, cases and readings on organisational entry, establishment, and change, Irwin, Homewood IL

Schein, E. H. (1984) 'Coming to a new awareness of organisational culture', Sloan Management Review, 25 (2), 3-16

Schein, E. H. (1990) 'Organisational Culture', American Psychologist, 45 (2), 109-119

Schein, E. H. (1993) 'Legitimating Clinical Research in the study of organisational culture', Journal of counseling and Development, 71 (6), 703-708

Schein, E. H. (1996) 'Three Cultures of management: The key to organisational learning', Sloan Management Review, 38 (1), 9-20

Schein, E. H. (2004) Organisational culture and leadership, Jossey-Bass, San Francisco

Schneider, B., Ed. (1990) Organisational climate and culture, Jossey-Bass, San Grancisco

Schultz, M. (1994) On Studying Organisational Cultures: Diagnosis and understanding, W De G, Berlin

Smircich, L. (1983a) 'Concepts of Cultures and Organisational Analysis', Administrative Science Quarterly, 28 (3), 339-358

Smircich, L. (1983b) 'Studying organisations as cultures', Morgan, G. (Ed.), Beyond Method, Sage, Beverly Hills

Smircich, L. (1985) 'Is the concept of culture a paradigm for understanding organisations and ourselves', Frost, P. J. More, L. F. Louis, M. R. Lundberg, C. C. and Martin, J. (eds.), Organisational Culture, Sage, California, 55-71

Smircich, L. and Calás, M. B., Eds. (1995) Critical perspectives on organisation and management theory, Dartmouth, Brookfield

Smithers, G. L. and Walker, D. H. T. (2000) 'The effect of the workplace on motivation and demotivation of construction professionals', Construction Management and Economics, 18, 833-841

Sveningasson, S. and Alvesson, M. (2003) 'Managing managerial identities: Organisational fragmentation, discourse and identity Struggle', Human Relations, 56 (10), 1163-1193

Toor, S-u-R and Ogunlana, S O (2008) 'Leadership skills and competencies for crosscultural construction projects', International Journal of Human Resources Development and Management, 8 (3), 192-215

Turner, J R (2006) 'Towards a theory of project management: The nature of the project', International Journal of Project Management, 24 (1), 1-3

Turner, J R and Muller, R (2003) 'On the nature of the project as a temporary organisation', International Journal of Project Management, 21 (1), 1-8

Usdiken, B. Soxen, Z. and Enbiyaoglu, H. (1988) 'Strategies and boundaries: subcontracting in construction', Strategic Management Journal, 9 (6), 633-637 
Vakola, M. and Wilson, I. E. (2004) 'The challenge of virtual organisation: critical success factors in dealing with constant change', Team Performance Management, 10 (5/6), 112-120 Van-Maanen, J. and Barley, S. R. (1985) 'Cultural Organisation. Fragments of a theory', Frost P. J. (Ed.), Organisational Culture, Sage, California, 31-53

Voordijk, H. Meijboon, B. and Haan, J. d. (2006) 'Modularity in supply chains: a multiple case study in the construction industry', International Journal of Operations \& Production Management, 26 (6), 600-618

Wainwright, D. and Waring, T. (2004) 'Three domains for implementing integrated information systems: redressing the balance between technology, strategic and organisational analysis', International Journal of Information Management, 24 (4), 329-346

Wakefield, R. L. Leidner, D. E. and Garrison, G. (2008) 'Model of conflict, leadership, and performance in virtual teams', Information Systems Research, 19 (4), 434-59

Walker, A. and Wing, C. K. (1999) 'The relationship between constriction project management theory and transaction cost economics', Engineering, Construction and Architectural Management, 6 (2), 166-176

Walker, D. H. T. Peters, R. J. Hampson, K. D. and Thompson, M. J. (2001) 'Achieving a responsive industrial relations environment for construction industry workers: a project aliancing case study', Construction Innovation, 1, 211-225

Wilkins, A. L. (1983) 'The Culture Audit: A tool for Understanding Organisations', Organisational Dynamics, 12 (2), 24-38

Wilkins, A. L. and Ouchi, W. G. (1983) 'Efficient Cultures: Exploring the relationship between culture and organisational performance', Administrative Science Quarterly, 28, 468-481

Willmott, H. (1997) 'Management and organisation studies as science', Organisation, 4 (3), 309-344

Winch, G. M. (1989) 'The construction firm and the construction project: a transaction cost approach', Construction Management and Economics, 7, 331-345

Winch, G. M. (2001) 'Governing the project process: a conceptual framework', Construction Management and Economics, 19, 799-808

Winch, G. Ushani, A. and Edkins, A. (1998) 'Towards total project quality: a gap analysis approach', Construction Management and Economics, 16, 193-207

Wong, J. Wong, P. N. K. and Heng, L. (2007) 'An investigation of leadership styles and relationship cultures of Chinese and expatriate managers in multinational construction companies in Hong Kong', Construction Management and Economics, 25 (1), 95-106

Yong, K. T. and Pheng, L. S. (2008) 'Organisational culture and TQM implementation in construction firms in Singapore', Construction Management and Economics, 26 (3), 237-248

Zaghloul, R. and Hartman, F. (2003) 'Construction contracts: the cost of mistrust', International Journal of Project Management, 21, 419-424

Zhang, S. B. and Liu, A. M. M. (2006) 'Organisational culture profiles and construction enterprise in China', Construction Management and Economics, 24 (8), 817-828

Zou, P. X. W. Fang, D. Wang, S. Q. and Loosemore, M. (2007) 'An overview of the Chinese construction market and construction management practice', Journal of Technology Management in China, 2 (2), 163-176 